\title{
Zoning of land reclamation in coal mining area and new progresses for the past 10 years
}

\author{
Wu Xiao $\cdot$ Zhenqi Hu $\cdot$ Yanhua Fu
}

Received: 10 July 2014/Revised: 28 July 2014/ Accepted: 2 August 2014/Published online: 30 September 2014

(C) The Author(s) 2014. This article is published with open access at Springerlink.com

\begin{abstract}
Coal mining disturbed land is the main sources of land reclamation in China. With the rapid increase of economy and coal production, more and more land has been disturbed by construction and coal mining; thus, land reclamation has become highlights in the past 10 years, and China is boosting land reclamation in mining areas. Disturbance characteristics vary from region to region, according to natural and geological conditions, coal mining area land reclamation was divided into 3 zones, which are eastern, western and southern. Reclamation strategies are focused on prime farmland protection in eastern and ecological restoration in western and southern zones, respectively. Several innovative reclamation technologies and theories for the past 10 years were introduced in this paper, including concurrent mining and reclamation, Yellow river sediments backfilling, self-reclamation, and topsoil alternatives in opencast mines. Besides, in the government regulation and legal system building respect, several important laws and regulations were issued and implemented in the past 5 years, promoting land reclamation management and supervision greatly. Land reclamation is and will still be one of the most important parts of coal industry in the future, and more efforts and funds are expected to get involved.
\end{abstract}

Keywords Land reclamation · Zoning · Concurrent mining and reclamation · Yellow river sediments · Self-reclamation . Land reclamation regulation

\section{Introduction}

Coal is the most important energy in China. With the excavation of coal resources, a lot of land was damaged and serious environmental problems were produced. Thus, coal mined land reclamation has become the important task for land protection and environmental conservation. In 2013, Coal mining outputs exceeded 3.7 billion tons in China, three times that of the United States, which is the

W. Xiao · Z. Hu $(\bowtie) \cdot$ Y. Fu

Institute of Land Reclamation and Ecological Restoration, China University of Mining and Technology (Beijing), Beijing 100083, China

e-mail: huzq1963@163.com world's second largest coal producer, of which $92 \%$ came from underground mining, ( $\mathrm{Hu}$ and Xiao 2013). The influence of coal mining to land and environment could be summarized in the paper.

\section{Impacts of coal mining}

\subsection{Impacts of coal mining on land}

Coal mining, including both surface and underground mining, has adverse impacts on land. Underground mining causes lots of land subsided and coal waste pile dumped on ground. Surface mining, requires large areas of land to be temporarily disturbed. This raises a number of environmental challenges, including soil erosion, dust, noise and water pollution, and impacts on local biodiversity. The influences of coal mining on land can be listed as follows: 


\subsubsection{Farmland lose}

In China, $92 \%$ of the coal outputs come from underground mining, with thousands of long wall panels underground. $\mathrm{Hu}$ and Luo (2006) indicated that overlap region (both a main coal production and agricultural production region) covered $40 \%$ of the total farmland in China, and it contained $58 \%$ of coal production and $45 \%$ of food production. High intensity extraction of coal underground results in large scale ground settlement, barren farmland, and decrease of cultivated land. It is estimated that the subsidence area is up to $0.533 \mathrm{hm}^{2}$, and low to $0.033 \mathrm{hm}^{2}$, with an average $0.2-0.33 \mathrm{hm}^{2}$, when 10 thousand tons of coal extracted underground. Subsidence land is expected to increase $2 \times 104 \mathrm{hm}^{2}$ annually (Hu 1996). According to the annual bulletin issued by Ministry of Land and Resource (MLR) in 2008, the cultivated land is decreased to $1.22 \times 108 \mathrm{hm}^{2}$ at the end of December 2008, which means the farmland per capita is only $0.09 \mathrm{hm}^{2}$. Therefore, underground mining induced farmland lose was a predominant impacts on land in China.

\subsubsection{Deforestation}

Surface mining requires large areas of land to be cleared so that the earth could be dug into by the miners. For this reason, large-scale deforestation is required to be carried out in the areas where mining has to be done (Hu 1997). Besides clearing the mining area, vegetation in the adjoining areas also needs to be cut in order to construct roads and residential facilities for the mine workers. The human population brings along with it other activities that harm the environment.

\subsubsection{Loss of biodiversity}

The forests that are cleared for mining purposes are home to a large number of organisms. Indiscriminate clearing of the forests leads to loss of habitat of a large number of animals. This puts the survival of a large number of animal species at stake ( $\mathrm{Li}$ et al. 2012).

\subsection{Other environmental issues}

The exploitation of mineral resources not only provided the energy and raw materials for the development of the national economy, but also caused the destruction of land and ecological environment such as land subsidence, solid waste and geological disasters; in the western ecological fragile area, coal mining also resulted in intensifying soil erosion and depletion of groundwater resources; the toxic gases produced by the spontaneous combustion of the coal gangue and the harmful substance leached from the coal gangue jointly polluted the air, water and soil in the mining area, bringing serious harm to the industrial and agricultural production and people's lives (Peng 2009).

Effects of mining on the environment may not be evident immediately; they are usually noticed after some years. Although the developed countries have tight norms regarding mining, such rules can be easily flouted in countries which lack strict monitoring of the procedures being followed for mining. The effects in such cases can be devastating for the environment.

\subsubsection{Geological disasters}

The adverse aspects of coal mining including coal waste occupation, digging of opencast, dumps, and ground subsidence, could lead to landslides, spontaneous combustion and explosion, cracks (Gu et al. 2012; Tan et al. 2012). Mining disasters bring great potential risks for urban development and public safety. The mine geological disaster is an important branch of geology disaster (Gao et al. 2012). In western and northern regions of China, secondary disasters caused by coal mining including:

(1) Major surface cracks, stairs, sinkholes by mining subsidence;

(2) Unstable slope of coal waste piles and open pit, which could cause landslides and mudslides.

In eastern region, most part of the area is comprised of plain, including North China plain and Huang-Huai-Hai plain. Coal mining impacts in this region are ground subsidence by underground mine, the groundwater table was relatively rising on the surface, forming polders and wetlands.

\subsubsection{Village movements}

China has the largest population in the world, which means lots of village residential being influenced greatly by mining subsidence, this situation was even worse in eastern China. Taking Huainan in Anhui Province as an example, by the end of 2006, coal mining subsidence area took up about $3.8 \%$ of the total area of land in Huainan. Almost 30,000 residential areas are influenced by mining subsidence, influenced the local village construction and villagers' production and living seriously, produced a large number of abandoned villages. According to news from the website, 414 thousand people might have to relocate there families because of coal mining underground in Juye coal mines, in Shandong province. It is estimated that the impacted population could reach to 2.73 million in 5 plain coal bases in eastern China, more than the Three Gorges migrants, which is only 1.39 million. 


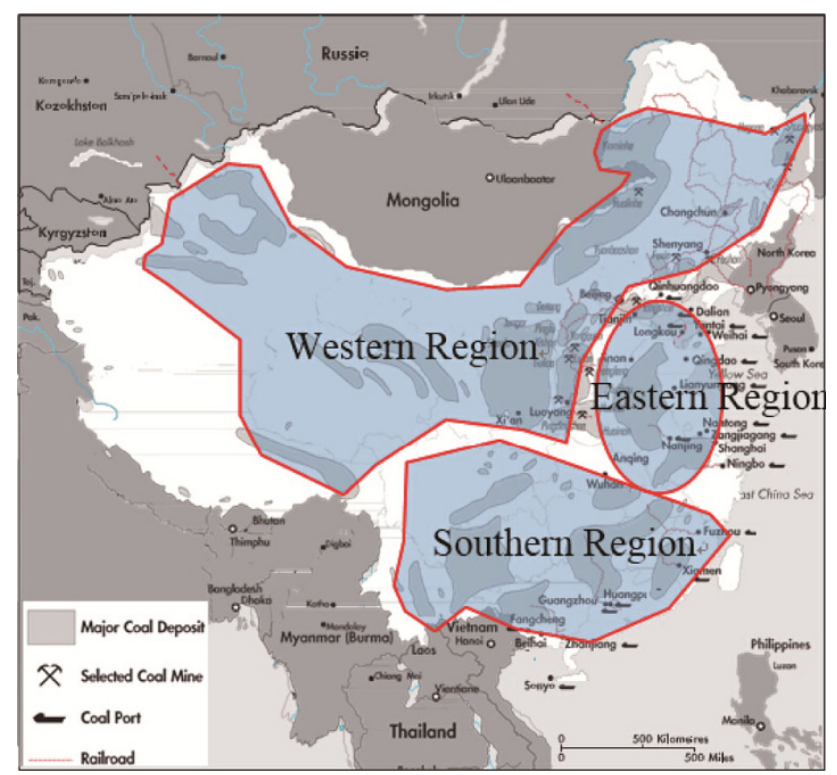

Fig. 1 Coal distribution and land reclamation partition in China (Source US DoE. EIA)

\subsubsection{Water and air pollution}

Despite of measures being taken to release the chemical waste into the nearby rivers through pipes, a large amount of chemicals still leak out onto the land, which changes the chemical composition of the land. Besides, since the chemicals are poisonous, they make the soil unsuitable for plants to grow. Also, the organisms that live in the soil find the polluted environment hostile for their survival. The leached acid drainage contains high concentrations of sulphate, iron and other metals (Hu et al. 2009), which could do harm to the surrounding biological.

With the rapid increase of economy and coal production, more and more land has disturbed by construction and coal mining, thus, land reclamation has become highlights in the past 10 years, and China is boosting land reclamation in mining areas. According to natural and geological conditions, mining regions were divided into eastern western, and southern. Reclamation strategies are focused on prime farmland protection in eastern and ecological restoration in western and southern, respectively. This paper introduced the new progress of land reclamation in China, including land reclamation technologies, polices, and laws.

\section{Coal distribution and land damage characteristics}

\subsection{Coal distribution}

China is the largest consumer of coal in the world, and is the largest user of coal-derived electricity. Coal reserves stood at 1.03 trillion tons as of 2006, which was the world's third-largest amount. Coal is largely used to generate electricity, produce building materials like cement and glass and produce steel. Coal distribution and partition was shown in Fig. 1.

\subsection{Land damage characteristics}

The damage manner and degrees are various due to geographical differences. In eastern China, a high groundwater region, subsidence land formed tremendous lakes and wetlands, $85 \%$ of which was cultivated land before mining.

In western China, a susceptible soil erosion and ecologically fragile area, mining subsidence has caused many environmental issues, such as soil erosion exacerbation, water resources deletion, ground water decline, vegetation cover reduction, land desertification. In southern China, a relatively warm and humid area, but with hilly terrain, mining subsidence induced landslide and mudslides severely endangering public safety. Therefore, land reclamation strategies have variation in different region. Land reclamation is focused on farmland protection, ecological restoration, and geological disaster prevention in eastern, western, and southern China, respectively.

\section{New progress of land reclamation technologies in China}

\subsection{Progress in eastern China}

\subsubsection{Concurrent mining and reclamation (CMR)}

Previous researches are focused on reclamation for stable subsidence land, which means half or even more land already submerged into water, including the fertilized topsoil, leading to an inefficient reclamation. From 2000, more and more scholars are emphasized on the reclamation for unstable subsidence land; many concepts like dynamic reclamation and pre-reclamation are proposed (Xiao et al. 2013). China University of Mining and Technology Beijing (CUMTB) pioneers in concurrent mining reclamation technology research. In 2003, CUMTB cooperated with Wanbei Coal Corporation (WCC), finished the project Dynamic Pre-reclamation Technology. The result was appraised by Ministry of Land and Resources, and implemented in Wanbei Coal Company. Base on those studies, CUMTB developed Dynamic Pre-reclamation Technology for High Groundwater Mining Subsidence Land in 2009, and won the second class of Science and Technology Improvement Award (MSTIA) by Ministry of Land and Resources. The technology is based on dynamic subsidence prediction, fully considered the dynamic changes between 

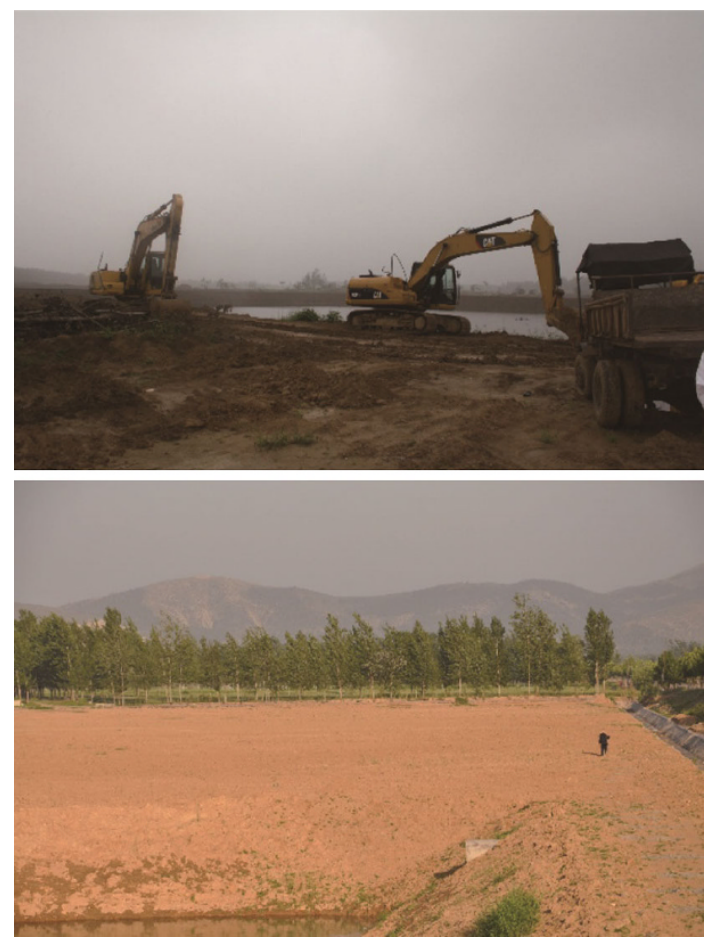

Fig. 2 Concurrent mining and reclamation practice

mining subsidence and fluctuation of groundwater, choosing the best reclamation time to strip topsoil which might submerge into water. The soil was then backfilled to farmland. Then, on one hand, fertilized topsoil was rescued; on the other hand, stripped soil guarantees enough filling material to reclaim farmland. Because reclamation was implemented while mining activities occurring, it is called Concurrent Mining and Reclamation (CMR).

According to the preliminary study, CMR could reclaim more than $20 \%$ of farmland when comparing with reclamation technologies for reclaiming stable subsidence land. Therefore, CMR are benefitial both to protecting and utilizing valuable topsoil resources, and reducing reclamation duration and abandoned time of disturbed land ( $\mathrm{Hu}$ et al. 2013a) (Fig. 2).

\subsubsection{Yellow river sediments backfilling}

Plain mining area is lack of filling materials. Coal mines adjacent to Yellow River (YR) could transport sediments from YR to fill subsidence land. After preliminary and feasibility study, the technology employs dredger and sand suction pump to excavate sediment from YR, and transported sediments to subsidence land through pipeline (Shao et al. 2013a, b). Assuming the pipeline is $60 \mathrm{~km}$ long, and excavating sediments for 260 days per year (considering dry seasons), transporting flow $3,900 \mathrm{~m}^{3} / \mathrm{h}$, sediment concentration $400 \mathrm{~kg} / \mathrm{m}^{3}$. It is estimated the transport sediment

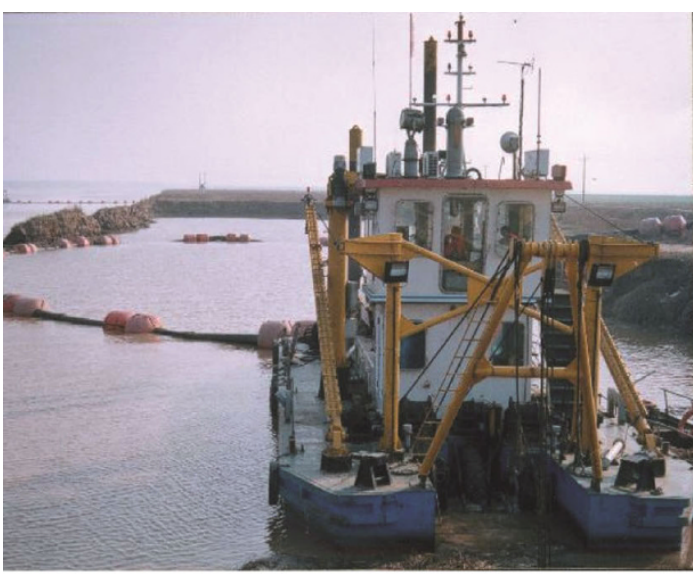

(a) Sediment collection

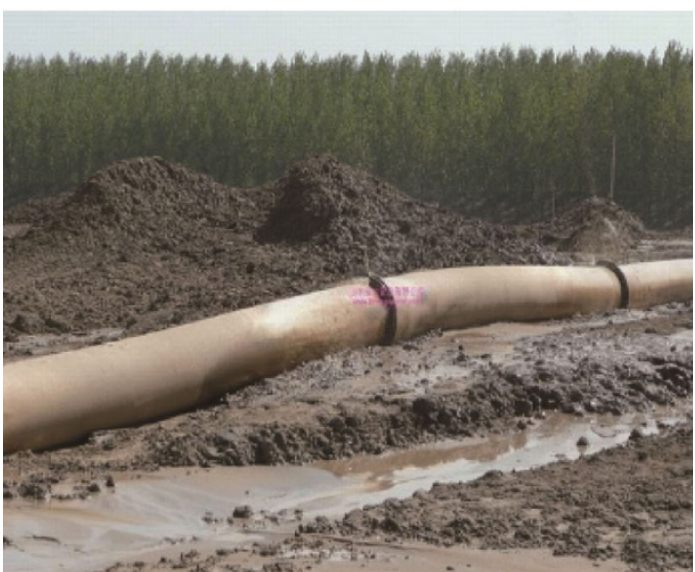

(b) Transportation

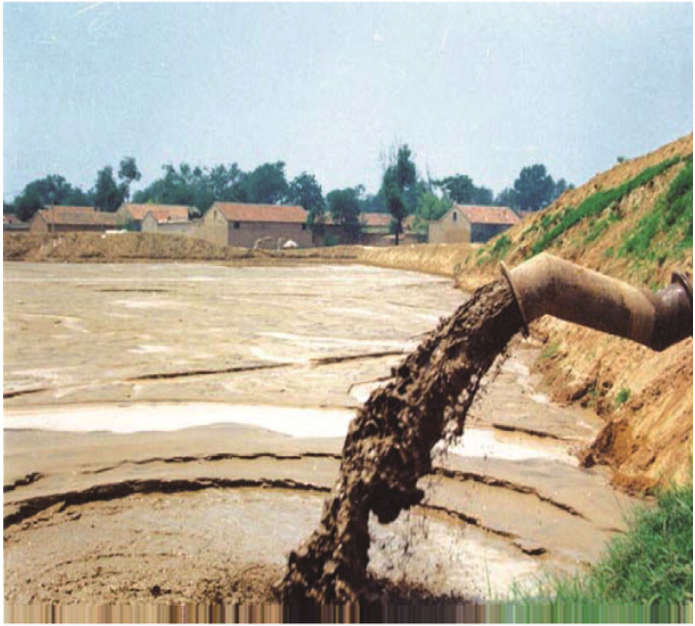

(c) Backfilling

Fig. 3 The process of Yellow River sediments backfilling

volume is 6.49 million $\mathrm{m}^{3}$ per year, and 260 hectares land could be reclaimed every year, the filling cost is 25.7 Yuan $/ \mathrm{m}^{3}$ (Fig. 3). 

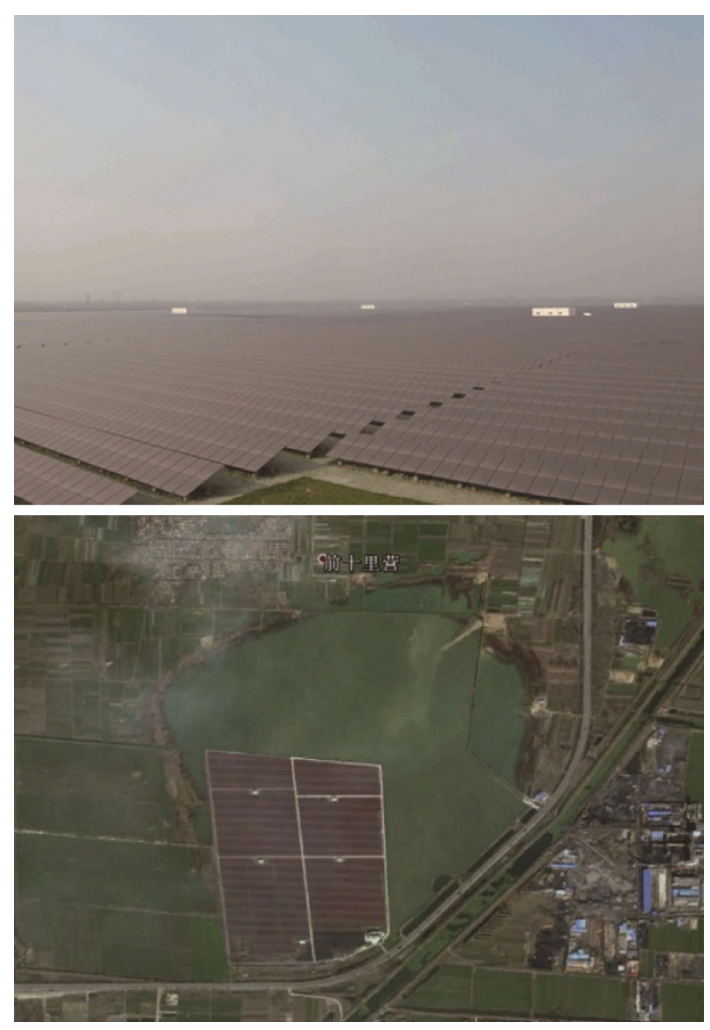

Fig. 4 Huahan solar photovoltaic power plant in southeast Jining city

The technology is not only conducive to reclaim subsidence land totally, but also could improve the YR flood and ecological environment. Currently, the research has been approved as a key project in the National Science \& Technology Support Program (NSTSP) of Twelfth 5th Plan by Ministry of Science and Technology in 2012. The research will focused on:

(1) Efficient excavation sediments technology in flowing water;

(2) Long-distance pipeline transport technology for YR sediments;

(3) Efficient de-waters and water recycling technology;

(4) Restore land with higher soil quality and productivity.

\subsubsection{Landscape reclamation of farmland and comprehensive utilization}

Land reclamation in eastern China was focused on the quantity of farmland. Subsided land will be reclaimed to farmland as priority. Over the past 10 years, more and more scholars and enterprise have realized the importance of landscape, especially in suburban (Fu et al. 2005, 2008). Besides, the ponds form by mining subsidence in plain area was also being utilized as solar photovoltaic power plant. Huahan solar photovoltaic power plant in southeast Jining city is the Asia's largest thin-film solar photovoltaic power plant. The total investment is 900 million Yuan, and the total size of the solar power plant would be $30 \mathrm{MW}$ (Fig. 4).

\subsection{Progress in Western and Southern China}

Reclamation strategies are focused on ecological restoration, environment protection, and soil erosion in western region. For the past 10 years, several new progress has achieved, which covers monitoring, self-reclamation, selection of topsoil alternatives.

\subsubsection{Monitoring and assessment of mining subsidence in Western China}

Coal mining activities are westward for the past 10 years. Lots of reverse impacts on land and environment have arisen because of sandy, arid, and ecologically fragile features. Underground coal mining activities lead to land subsided and soil erosion subsequently. Many debates exists about the extent of land damages, therefore, more and more scholars have paid attention to the monitoring and assessment of mining subsidence in this area. Bian et al. (2009) analyzed soil moisture in arid mining area based on TM images. Based on field survey, distribution characteristic of marginal fissures, genesis and development rules of dynamic fissures and their relationship with mining geological conditions were revealed by $\mathrm{Hu}$ et al. (2014). Surface ground ecological damages would have a self-restoration in tendency under the natural force role. An artificial guided ecological restoration mode and method with the partition restoration, damage reduction and plant promotion as the key was provided (Zhang et al. 2013).

\subsubsection{Land reclamation of dumps and monitoring}

Dumps are the main reclamation object in western China. Wang et al. (2012, 2013) monitored the effect of land reclamation on soil quality and its relationship between plants and soil in time domain. The typical plot survey method was used to analyze the dynamic succession law of soil environmental factors and vegetation biomass with reclamation years $(3,5,10,12$ and 17 years) in the Shanxi Antaibao opencast coal mine dump. A logistic succession model of reclaimed soil environmental factors and vegetation biomass land arbor forest in the loess area opencast mine dump were constructed in this study, and the interactions of partial differential equations between soil and vegetation were built. 


\subsubsection{Topsoil alternatives based on bedrock}

Selection of topsoil alternatives is very important for surface mined land reclamation in the region of topsoil shortage. Hu et al. (2013a) conducted research on the selection of topsoil alternatives from overburden of a surface coalmine in Inner Mongolia, which is located in the famous Hulun baier grassland. The results indicated that Layer 3 had similar soil chemical and physical properties and better seed germination compared with the original topsoil, and could be good topsoil alternatives. The weathering material of Layer 3 was the best for topsoil alternatives.

\section{Policies and laws}

In the government regulation and legal system building respect, several important laws and regulations were issued and implemented by the past 5 years.

On March 5, 2011, the State Council issued and implemented Land Reclamation Regulation (No.592 Order of the State Council of the People's Republic of China). It marks that China's land reclamation career entered into a new stage with cooperation of institution, standardization and legalization. LRR includes six chapters and 44 articles. Compared with the "Stipulation on Land Reclamation" (SLR), which was issued in 1988, the main differences can be summarized by the following several aspects: firstly the definition of the reclamation object is more comprehensive. In addition to the damaged land by production and construction activities, damaged land by natural disasters is taken into consideration; secondly, it has clarified the main responsibility of the land reclamation; thirdly, it has perfected the land reclamation obligations constraint mechanism; fourthly, the land reclamation incentive mechanism has been strengthened; fifthly, the department's responsibility is clarified further.

Based on LRR, Implementation Measures on Land Reclamation Regulation (IMLRR) was also issued on December 11, 2012. IMLRR is a detailed regulation on LRR. Regulation on Compiling Land Reclamation Plan (RCLRP) was issued in 2011, RCLRP contains 7 parts, which are general rules, opencast coalmine, underground coal mine, metal mine, petroleum and natural gas (including coal-bed gas), construction projects, and uranium mine. Besides, Completion Standards on Land Reclamation Quality (CSLRQ) was issued in 2013 with approval number TD/T 1036-2013, CSLRQ are concentrated on the land reclamation quality.

\section{Outlooks and prospects}

Land strategies are different because of the natural and geological aviation in China. By the past 5 years, many important laws and regulation has successively promulgated, and promote land reclamation greatly. Land reclamation researches are focused on prime farmland protection in eastern China and ecological restoration in western and southern China. With the rapidly economic development, corporate social responsibility and public awareness advance further. More and more attention has been paid to land reclamation area. Land reclamation are and will still be one of the most important parts of coal industry in the future, and more efforts and funds are expected to get involved.

Open Access This article is distributed under the terms of the Creative Commons Attribution License which permits any use, distribution, and reproduction in any medium, provided the original author(s) and the source are credited.

\section{References}

Bian ZF, Lei SG, Chang LQ, Zhang RC (2009) Affecting factors analysis of soil moisture for arid mining area based on TM images. J China Coal Soc 34(4):520-525

Fu MC, Hu ZQ, Wu GG (2005) Analysis of evolutionary law of farm land landscape. Trans Chin Soc Agric Eng 21(6):54-58

Fu MC, Hu ZQ, Wu, Liu S (2008) Farmland restoration and pollution prevention in the overlapped area of crop and mineral production. Met Mine 38(7):119-122

Gao F, Zhou KP, Chen XY, Luo XW (2012) Disaster chains induced by mining and chain-cutting disaster mitigation technology. Disaster Adv 10:5

Gu ST, Wang CQ, Jiang BY, Tan YL, Li NN (2012) Field test of rock burst danger based on drilling pulverized coal parameters. Disaster Adv 5(4):237-240

$\mathrm{Hu}$ ZQ (1996) Coal mining subsidence of the land resource management and land reclamation. Coal Industry Press, Beijing

Hu ZQ (1997) Principle and method of soil profile reconstruction for coal mine and reclamation. J China Coal Soc 22(6):617-622

Hu ZQ, Luo YM (2006) Problems, reasons and countermeasures for environmental quality and food safety in the overlapped areas of crop and mineral production. Sci Technol Rev 24(3):93-94

$\mathrm{Hu}$ ZQ, Xiao W (2013) Optimization of concurrent mining and reclamation plans for single coal seam: a case study in northern Anhui, China. Environ Earth Sci 68(5):1247-1254

Hu ZQ, Zhang ML, Ma BG, Wang P, Kang JT (2009) Fly ash for control pollution of acid and heavy metals from coal refuse. J China Coal Soc 34(1):79-83

Hu ZQ, Wei BL, Lin S, Yang J, Li Y (2013a) Selection of topsoil alternatives from overburden of surface coal mines. Trans Chin Soc Agricu Eng 29(19):209-214

Hu ZQ, Xiao W, Fu YH (2013b) Introduction to concurrent mining and reclamation for coal mines in China. Twenty second international symposium on Mine Planning \& Equipment Selection. Dresden/Freiberg Germany, 14-19 Oct 2013 pp. 781-789 
Hu ZQ, Wang XJ, He AM (2014) Distribution characteristic and development rules of ground fissures due to coal mining in windy and sandy region. J China Coal Soc 39(1):11-18

Li BJ, Gu HH, Ji YZ (2012) Evaluation of landscape pattern changes and ecological effects in land reclamation project of mining area. Trans CSAE 28(3):251-257

Peng SP (2009) China coal resource exploitation and environmental protection. Sci Technol Rev 27(17):1-10

Shao F, Wang PJ, Li EL, Jiang ZD, Qiao ZY, Liu DW, Chen YK (2013a) The feasibility of application of desilting and drainage engineering measures in the process of filling reclamation with Yellow River sediment. Energy Environ Prot 27(3):1-5

Shao F, Wang PJ, Hu ZQ, Zeng JY, Chen YK, Li EL (2013b) Vertical infiltration characteristics of reclamation farmland soil filled with Yellow River sediment. J Soil Water Conserv 27(5):54-58
Tan YL, Zhang Z, Ma CL (2012) Rock burst disaster induced by mining abutment pressure. Disaster Adv 10:5

Wang JM, Yang RX, Bai ZK (2012) Succession law and model of reclaimed soil quality of opencast coal mine dump in grassland. Trans Chin Soc Agric Eng 28(14):229-235

Wang JM, Guo LL, Bai ZK, Yang RX, Zhang M (2013) Succession law of reclaimed soil and vegetation on opencast coal mine dump of loess area. Trans Chin Soc Agric Eng 29(21):223-232

Xiao W, Hu ZQ, Zhang RY, Zhao YL (2013) A simulation of mining subsidence and its impacts to land in high ground water area-an integrated approach based on subsidence prediction and GIS. Disaster Adv 6(S4):142-148

Zhang JM, Li QH, Hu ZQ, Wang Y, Li Q (2013) Study on ecological restoration mode of ultra wide fully- mechanized coal mining in west China Aeolian Sand area. Coal Sci Technol 41(9):173-177 